\title{
Impact of adipose tissue in chronic kidney disease development (Review)
}

\author{
DANIELA MIRICESCU ${ }^{*}$, DANIELA GABRIELA BALAN ${ }^{2 *}$, ADRIAN TULIN $^{3,4}$, OVIDIU STIRU $^{5,6}$, \\ ILEANA ADELA VACAROIU $^{7,8}$, DOINA ANDRADA MIHAI ${ }^{9,10}$, CRISTIAN CONSTANTIN POPA ${ }^{11,12}$, \\ MIHALY ENYEDI ${ }^{3,13}$, ANDREI SORIN NEDELEA ${ }^{14}$, ADRIANA ELENA NICA ${ }^{15}$ and CONSTANTIN STEFANI ${ }^{16^{*}}$ \\ ${ }^{1}$ Department of Biochemistry, ${ }^{2}$ Discipline of Physiology, Faculty of Dental Medicine, and ${ }^{3}$ Department of Anatomy, \\ Faculty of Medicine, 'Carol Davila' University of Medicine and Pharmacy, 020021 Bucharest; \\ ${ }^{4}$ Department of General Surgery, 'Prof. Dr. Agrippa Ionescu' Clinical Emergency Hospital, 011356 Bucharest; \\ ${ }^{5}$ Department of Cardiovascular Surgery, Faculty of Medicine, 'Carol Davila' University of Medicine and Pharmacy, \\ 020021 Bucharest; ${ }^{6}$ Department of Cardiovascular Surgery, 'Prof. Dr. C.C. Iliescu' Emergency Institute for
} Cardiovascular Diseases, 022322 Bucharest; ${ }^{7}$ Department of Nephrology and Dialysis, 'Sf. Ioan’ Emergency Clinical Hospital, 042122 Bucharest; ${ }^{8}$ Department of Nephrology, ${ }^{9}$ Discipline of Diabetes, Nutrition and Metabolic Diseases, Faculty of Medicine, 'Carol Davila' University of Medicine and Pharmacy, 020021 Bucharest; ${ }^{10}$ Department II of Diabetes,

'Prof. N. Paulescu' National Institute of Diabetes, Nutrition and Metabolic Diseases, 020474 Bucharest;

${ }^{11}$ Department of Surgery, Faculty of Medicine, 'Carol Davila' University of Medicine and Pharmacy, 020021 Bucharest;

${ }^{12}$ Department of Surgery, Bucharest Emergency University Hospital, 050098 Bucharest; ${ }^{13}$ Department of Radiology,

'Victor Babes' Private Medical Clinic, 030303 Bucharest; ${ }^{14}$ Department of Urology,

'Prof. Dr. Agrippa Ionescu' Clinical Emergency Hospital, 011356 Bucharest; ${ }^{15}$ Department of Orthopedics,

Anesthesia Intensive Care Unit, Faculty of Medicine, 'Carol Davila' University of Medicine and Pharmacy, 020021 Bucharest; ${ }^{16}$ Department of Family Medicine and Clinical Base,

Dr. Carol Davila Central Military Emergency University Hospital, 010825 Bucharest, Romania

Received December 15, 2020; Accepted January 14, 2021

DOI: $10.3892 /$ etm.2021.9969

\begin{abstract}
Obesity is a worldwide pandemic health issue. Obesity is associated with the pathogenesis of type 2 diabetes, hypertension, dyslipidemia, cardiovascular diseases, cancer, and kidney diseases. This systemic disease can affect the kidneys by two mechanisms: Indirectly through diabetes mellitus (DM) and hypertension and directly through adipokines secreted by adipose tissue. Obesity is a risk factor for chronic kidney disease (CKD), which is associated with an increased risk of morbidity and mortality among the adult population. Increased visceral adipose tissue leads to
\end{abstract}

Correspondence to: Dr Daniela Gabriela Balan, Discipline of Physiology, Faculty of Dental Medicine, 'Carol Davila' University of Medicine and Pharmacy, 37 Dionisie Lupu Street, 020021 Bucharest, Romania

E-mail: gdaniela.balan@yahoo.com

*Contributed equally

Key words: obesity, chronic kidney disease, adipokines, endocrine organ, glomerulopathy, inflammation renal glomerular hyperfiltration and hyperperfusion, which may lead to glomerular hypertrophy, proteinuria, and CKD development. Adipokines are hormones produced by fat tissue. They are involved in energy homeostasis, sugar and fat metabolism, reproduction, immunity, and thermogenesis control. Hormones and cytokines secreted by adipose tissue contribute to the development and progression of CKD. Decreased serum or urinary adiponectin levels are specific in diabetic and non-diabetic CKD patients, while leptin presents increased levels, and both are associated with the development of glomerulopathy. Excessive adipose tissue is associated with inflammation, oxidative stress (OS), insulin resistance and activation of the renin angiotensin-aldosterone system (RAAS). Therefore, adipose tissue dysfunction plays an important role in the development of CKD.

\section{Contents}

1. Introduction

2. Obesity and CKD

3. Adipose tissue as an endocrine organ

4. Adiponectin and CKD

5. Leptin and CKD

6. Conclusions 


\section{Introduction}

The kidney is responsible for multiple vital functions in the body. It regulates blood volume and pressure, reabsorbs nutrients, excretes wastes, and secretes hormones $(1,2)$. Thyroid hormones are involved in renal development, kidney hemodynamics, glomerular filtration rate (GFR), sodium, and water homeostasis. Hypothyroidism and hyperthyroidism affect renal function (3). Acute kidney injury (AKI), chronic kidney disease (CKD), end stage renal disease (ESRD), kidney stones and kidney cancer-renal cell carcinoma, represent major kidney pathologies (3-6). AKI and CKD are associated with an increased risk of morbidity and mortality. AKI is a rapid and reversible decline in renal function and evolves rapidly to CKD (7). This acute renal injury is diagnosed based on an increase in the serum creatinine level of above $\geq 0.3 \mathrm{mg} / \mathrm{dl}$ $(\geq 26.5 \mu \mathrm{mol} / \mathrm{l})$ within $48 \mathrm{~h}$; an increase in serum creatinine to $\geq 1.5$ times baseline; or urine volume $<0.5 \mathrm{ml} / \mathrm{kg} / \mathrm{h}$ for $6 \mathrm{~h}$ (8). Drugs (including non-steroidal anti-inflammatory compounds), toxins, diuretics, sepsis, age, genetic factors, race, diabetes mellitus (DM), and hypertension are risk factors for AKI, which may lead to reduced GFR and further to acute tubular cell destruction (9). Worldwide, CKD is an urgent medical issue, with a rapidly increasing incidence particularly in diabetic and hypertensive patients, predisposing these patients to diabetic nephropathy, hypertensive nephrosclerosis and focal and segmental glomerulosclerosis (10-14). Anemia, dyslipidemia, malnutrition, mineral and bone disorders, are the most common complications in CKD patients (15).

The presence of albuminuria or estimated GFR (eGFR) from serum creatinine $<60 \mathrm{ml} / \mathrm{min} / 1.73 \mathrm{~m}^{2}$, is the main diagnostic criterion for CKD (16). According to the Kidney Disease Quality Outcome Initiative (K/DOQI), CKD is defined as kidney damage or GFR less than $60 \mathrm{ml} / \mathrm{min} / 1.73 \mathrm{~m}^{2}$ for 3 months or more, irrespective of the cause (17). GFR is measured from calibrated serum creatinine and estimating equations, such as the Modification of Diet in Renal Disease (MDRD) study equation or the Cockcroft-Gault formula (17).

Albuminuria is the most commonly used marker to reflect kidney damage, and elevated levels are associated with an increased risk of CKD and ESRD, independent of eGFR. Based on severity, albuminuria is classified as A1 (albuminuria $<30 \mathrm{mg} / \mathrm{g}$-optimal or normal), A2 (albuminuria $30-300 \mathrm{mg} / \mathrm{g}$-high) and A3 (albuminuria $>300 \mathrm{mg} / \mathrm{g}$-very high) (18).

Previous studies have previously described CKD stages (18-21). CKD is an independent risk factor for many systemic disorders such as, angina, acute myocardial infarction, heart failure, stroke, peripheral vascular disease, and arrhythmias (13). According to the World Health Organization (WHO), obesity is considered a disease (22). In the Western world, obesity rates are increasing rapidly, which mirrors the increase in comorbidities such as cancer, cardiovascular diseases, diabetes, and CKD (22). Obesity is involved in the progression of CKD in two ways: Indirectly through DM and hypertension or directly through adipose tissue (13,22-26). According to the WHO, the definition of obesity is based on body mass index (BMI) as follows: Underweight $\left(<18.5 \mathrm{~kg} / \mathrm{m}^{2}\right)$, normal weight $\left(18.5-25 \mathrm{~kg} / \mathrm{m}^{2}\right)$, overweight $\left(25-30 \mathrm{~kg} / \mathrm{m}^{2}\right)$ and obese $\left(>30 \mathrm{~kg} / \mathrm{m}^{2}\right)$, obese class I $\left(30.0-34.9 \mathrm{~kg} / \mathrm{m}^{2}\right)$, obese class II $\left(35-39.9 \mathrm{~kg} / \mathrm{m}^{2}\right)$ and obese class III $\left(>40 \mathrm{~kg} / \mathrm{m}^{2}\right)(27)$. Between 1975 and 2016, the worldwide incidence of obesity was found to triple, with a high prevalence of overweight individuals (over 30\%) and obesity (over 10\%) (27). Moreover, childhood obesity is currently increasing worldwide $(27,28)$. In Europe, one child out of 3 is overweight or obese, and over $60 \%$ of them will be overweight before puberty or overweight in early adulthood $(27,28)$.

Initially, adipose tissue was considered a passive reservoir for energy storage, involved in mechanical and heat insulation, involved in thermogenesis regulation. However, adipose tissue secretes various bioactive peptides, called 'adipokines', which are involved in both autocrine/paracrine and endocrine activity (29). Thus, adipose tissue may directly affect the kidney through its endocrine activity via the production of adiponectin, leptin, and other adipokines (22).

\section{Obesity and CKD}

Increased body weight is associated with lower urine $\mathrm{pH}$, increased urinary oxalate and the excretion of sodium, phosphate, and uric acid (30-32). Obesity is also involved in nephrolithiasis pathogenesis $(33,34)$.

Studies have revealed that individuals presenting with no kidney disease but with higher BMI, develop proteinuria $(22,35)$. Patients who do not present with DM and hypertension, but who present with juvenile obesity, may present a 3-fold increased risk of CKD (36). Fox et al published the results of a study over a 19-year period involving 2,585 individuals. The authors observed that BMI predicted new onset kidney diseases (37). In patients with pre-existing CKD, it was also observed that increased levels of BMI led to a rapid progression of CKD (22). In obesity, the kidneys are compressed by increased visceral and retroperitoneal fat, which may increase blood pressure. Moreover, excess fat accumulation in and around the kidneys conduces to increased intra-renal pressure, impaired pressure natriuresis, and hypertension (38). In patients with visceral obesity, intra-abdominal pressure rises to $35-40 \mathrm{mmHg}$, in proportion to sagittal abdominal diameter, which leads to compression of the renal veins, lymph vessels, ureters and renal parenchyma. Increased sagittal abdominal diameter is associated with increased intra-abdominal pressure which leads to obesity-related comorbidity, such as type II diabetes, hypertension, and CKD (39).

Previous studies performed on obese dogs, rabbits and even humans have demonstrated that retroperitoneal fat encapsulates the kidneys, adheres tightly to the renal capsule, and invades the renal sinuses, causing additional compression and increasing intra-renal pressure $(40,41)$. Animals fed a hypercaloric diet, such as rabbits, accumulate fat in the renal sinuses, followed by the distortion and prolapse of the renal medullary ducts of Bellini, and urinary outflow restriction $(42,43)$. In obese adults, a higher amount of retroperitoneal and renal sinus fat is associated with hypertension. Moreover, higher BMI seems to be correlated with a decrease in GFR, which will conduce over time to a rapid loss of GFR, and an increased incidence of ESRD (44). In obese adults, central obesity is associated with a $70 \%$ increased risk of microalbuminuria when compared with lean adults (45). 
Obesity can alter renal hemodynamics through two pathogenic mechanisms: Glomerular hyperperfusion and hyperfiltration $(46,47)$. To describe glomerular hyperperfusion and hyperfiltration, Henegar et al conducted a study on non-obese dogs fed a high-fat diet for 7-9 or 24 weeks. The study reported increased blood pressure, pulse rate, GFR and renal plasma flow in the obese vs. the lean dogs. Increased plasma levels of insulin and renin were detected in dogs treated with the fat diet, compared with the control group. The histological analysis revealed enlarged Bowman's space, increased glomerular cell proliferation, increased mesangial expression, thickening of the basement membranes and even higher expression for renal transforming growth factor (TFG) $-\beta$. Interestingly, the study did not find any association between the glomerulosclerosis score of the obese dogs and the lean dogs. Acute obesity did not conduce to renal scarring, instead chronic obesity was involved in renal scarring (46). Chronic obesity contributes to CKD progression by glomerular hyperfiltration, microalbuminuria/proteinuria development, hypofiltration and decreased GFR (48-50).

Ectopic lipid accumulation, together with renal sinus fat accumulation, may lead to glomerular hypertension development and increased glomerular permeability, caused by the hyperfiltration associated with glomerular filtration barrier damage, leading to glomerulomegaly and focal or segmental glomerulosclerosis (51-54).

Glomerular hyperfiltration, glomerular hypertrophy and increased filtration fraction promote proteinuria and glomerulosclerosis, processes that further stimulate the renin angiotensin-aldosterone system (RAAS), release of TGF- $\beta$, a cascade of events that cause kidney damage (55).

Adipose tissue expresses all RAAS components; angiotensin receptors 1 and 2 are present in human and animal adipocytes $(56,57)$. Sodium retention and aldosterone secretion are normal RAAS functions, but in adipose tissue it may be involved in obesity-related hypertension. Moreover, adipocytes from inflamed visceral and perivascular tissues are involved in RAAS activation (58). In obese individuals, increased levels of angiotensin II, directly contribute to the increase in oxidant stress (OS) at the vascular level (59). Boustany et al conducted a study on rats fed a high-fat diet for 11 weeks to induce obesity. The results of the study revealed higher systemic blood pressure, increased levels of the plasmatic angiotensin and angiotensin gene expression in the retroperitoneal adipose tissue (60).

In patients with metabolic syndrome, which is characterized by the presence of hypertension, dyslipidemia and insulin resistance, angiotensin II presents higher levels (61). Adipocytes may contribute up to $30 \%$ to the production of circulating angiotensinogen II (58). Increased angiotensin II levels affect renal hemodynamic, contributing to hyperfiltration, glomerulomegaly, and further focal glomerulosclerosis via afferent arteriolar dilation. Moreover, afferent renal arteriolar vasoconstriction, angiotensin II with endocrine and paracrine properties, links the intrarenal and the systemic RAAS. Adipose tissue dysfunction, together with insulin resistance and hypertension contributes to CKD development and eventually to ESRD (61). In vascular tissue, aldosterone may induce mineralocorticoid receptor activation, promoting vascular stiffness caused by oxidative stress (OS) (62), inflammation (63), maladaptive immune modulation, and fibrosis (58).

\section{Adipose tissues as an endocrine organ}

White adipose tissue exhibits endocrine, paracrine, and autocrine activities. The adipocytes secreted are involved in body weight regulation (leptin and adiponectin), in local inflammation (TNF- $\alpha$, IL-6 and IL-1 $\beta$ ), in vascular function and even in breeding (64). Cytokines, hormones, leptin, and adiponectin are secreted also by brown adipose tissue, which acts as an endocrine organ (64). The last form of adipose tissue, perivascular adipose tissue, is located around the coronary artery, the aorta (periaortic adipose tissue), and the microcirculatory bed of the kidney and adipose tissue, which releases adiponectin, leptin, interleukin (IL)-6, and tumor necrosis factor (TNF)- $\alpha$. In men, the most common form of obesity is central or abdominal obesity, and consists of an accumulation of visceral adipose tissue (64). According to various studies, this type of obesity has been associated, with a higher risk of diseases such as insulin resistance, type 2 diabetes, and cardiovascular risk (65-67). Adipose tissue presents a variety of cell populations such as macrophages, endothelial cells, fibroblasts, and leukocytes (64). Hypercaloric diet consumption induces lipid accumulation in adipocytes, triggering cellular stress and activation of c-Jun $\mathrm{N}$-terminal kinase (JNK) and nuclear factor $\kappa$-light-chain-enhancer of activated B cells (NF- $\kappa B$ ) signaling pathways (64). These inflammatory signaling pathways are involved in the phosphorylation of different proteins and transcriptional factors, causing an increased secretion of proinflammatory molecules (TNF- $\alpha$, IL-6), leptin, chemokines [monocyte chemoattractant protein 1 (MCP-1)], and proatherogenic mediators [plasminogen activator inhibitor-1 (PAI-1)] (64). Obesity can be defined as a proinflammatory state of low grade, where the adipokine secretion increases with visceral fat mass. IL- 6 and TNF- $\alpha$ activate the production of other inflammatory cytokines, such as $\mathrm{C}$-reactive protein (CRP) $(59,64)$. Inflammation is associated with leukocyte infiltration, via NADPH oxidase and reactive oxygen species (ROS) generation. Hydroxyl radical (HO'), anion superoxide radical $\left(\mathrm{O}_{2}^{-*}\right)$ and hydrogen peroxide $\left(\mathrm{H}_{2} \mathrm{O}_{2}\right)$ are ROS generated by inflammatory pathways, adipokine increased levels (leptin) and leukocyte infiltration in white adipose tissue (59). In isolated adipocytes, it was reported that TNF- $\alpha$ suppresses insulin signal transduction and expression of the insulin receptor, leading to hyperglycemia, and even to pancreatic $\beta$-cell destruction. Hyperglycemia induces OS (59).

Obesity stimulates the production of leptin, which further increases OS, activity of the sympathetic nervous system (SNS) similar to sleep deprivation (68) leading to glomerulosclerosis, renal fibrosis and finally proteinuria (69). In obese patients, renal compression conduces to increased sodium reabsorption, promoting renal vasodilatation, glomerular hyperfiltration, and increased renin secretion (38). Fat accumulation in and around the kidney, leads to OS, mitochondrial dysfunction, and endoplasmic reticulum stress (70).

\section{Adiponectin and CKD}

Adipocytes secrete adiponectin, a 26.4-kDa protein, which presents in healthy individuals and has anti-inflammatory, anti-atherogenic and insulin-sensitizing properties, being involved in lipid and glucose metabolism, partially through 
activation of AMPK (69,71). Decreased levels of adiponectin are associated with several systemic disorders such as insulin resistance, obesity, type II diabetes (early stages) and dyslipidemia (72). Adiponectin levels are significantly decreased in obesity, being negatively correlated with the percent of fat mass (72). Based on distributions and molecular affinities of adiponectin complexes, adiponectin presents two receptors. Adiponectin receptor 1 (AdipoR1) is mainly expressed in skeletal muscle and is moderately expressed in other tissues, such as heart and brain (73). At the renal level, AdipoR1 is found in the glomerulus and proximal tubule. AdipoR2 is predominantly expressed in the liver. Adiponectin binds to AdipoR1 and AdipoR2 and further activates the AMPK signaling pathway which is involved in energy homeostasis (73). Moreover, adiponectin activates in vitro the MAPK signaling pathway, increasing glucose uptake (73).

Kuo and co-researchers conducted a study which included 196 non-diabetic CKD patients with eGFR ranging between 10 and $60 \mathrm{ml} / \mathrm{min} / 1.73 \mathrm{~m}^{2}$, divided into two groups based on the presence of metabolic syndrome. The study reported, over a period of 5 years, $48(24.5 \%)$ incident cases of end-stage renal disease (ESRD) and $33(16.8 \%)$ deaths. Adiponectin levels were inversely related to $\mathrm{BMI}(\mathrm{r}=-0.29 ; P<0.001)$ and waist circumference $(\mathrm{r}=-0.35 ; \mathrm{P}<0.001)$. A decreased adiponectin level was associated with a higher risk of ESRD independent of conventional risk factors, BMI, and even metabolic syndrome (74).

Coimbra et al studied 194 ESRD patients on dialysis and 22 controls and evaluated the lipid profile [lipoprotein subpopulations and oxidized LDL (oxLDL)], CRP, adiponectin, leptin, and paraoxonase 1 activity. In diabetic and obese patients $(n=45)$ they observed the lowest values for adiponectin vs. the normoponderal patients $(\mathrm{n}=81)$ (75). Yaturu et al studied 43 subjects with CKD and 34 control subjects and evaluated plasma and urinary levels of adiponectin. In patients with CKD, the plasma levels of adiponectin were not decreased compared with the controls. The study revealed a negative correlation between urinary adiponectin levels and GFR $(r=-0.4 ; \mathrm{P}<0.05)$ and a positive correlation with plasma adiponectin levels $(\mathrm{r}=0.9 ; \mathrm{P}<0.0001)$ (76). Moreover, increased consumption of sugars was found to lead to obesity (77) and further to a decreased level of adiponectin (72).

Regarding anti-inflammatory effects, adiponectin was found to suppress IL- 6 and TNF- $\alpha$ expression, which are activated by NF- $\mathrm{kB}$. Adiponectin was found to bind to its two receptors and to activate adaptor protein containing a pleckstrin homology domain 1 (APPL1) (78). Once activated, APPL1 was found to further activate peroxisome proliferator-activated receptor- $\alpha$ (PPAR- $\alpha$ ) and phosphorylation of 5'activated protein kinase (AMPK), and mitogen-activated protein kinase (p38-MAPK) was found to occur (78). Phospho-AMPK downstream was found to phosphorylate acetyl-CoA carboxylase (ACC), promote fatty acid oxidation, and inhibit lipogenesis. Phosphorylation of endothelial nitric oxide synthase (eNOS) by AMP was found to stimulate NO production, which results in vasodilation (78). In inflammation, adiponectin presents a cytoprotective effect, activates AMP, suppresses mammalian target for rapamycin (mTOR) and the inhibitor of nuclear factor $\kappa B$ kinase subunit $\gamma$-phosphatase and tensin homology (IKK-NF-kB-PTEN) signaling pathways (78). The phosphatidylinositol 3-kinase-protein kinase B (PI3K-AKT) signaling pathway controls the metabolic effects of insulin, which is involved in glycogen synthesis, increases glucose uptake, inhibits lipolysis also being involved in other physiological processes such as motility (78). Adiponectin may activate insulin receptor substrate $1 / 2$ (IRS1/2) increasing insulin sensitivity (78).

Hypoadiponectinemia is associated with CKD. A potential mechanism for this was identified in mice presenting with hypoadiponectinemia. These mice exhibit podocyte fusion with adiponectin treatment improving the glomerular podocyte foot processes via activation of AMPK, which downregulates podocyte NADPH oxidase (Nox)4. Importantly, these mice exhibit albuminuria, clearly demonstrating a link between hypoadiponectinemia and kidney dysfunction (79). Moreover, podocytes present AdipoR1, an alteration of the receptor that may lead to obesity-related dysfunction. Increased urinary levels of both the low- and high-molecular-weight isoforms of adiponectin were detected in patients with established kidney disease and patients with type 2 diabetes (79). In vivo, it has been observed that only a week of consuming a high-fat diet, contributes to kidney inflammation, which is associated with albuminuria, and further triggers urinary excretion of monocyte chemotactic protein (MCP-1) and $\mathrm{H}_{2} \mathrm{O}_{2}(79)$.

\section{Leptin and CKD}

Leptin is a small peptide hormone, secreted mainly by visceral, subcutaneous, and pericardial adipose compartments, but can be produced even by normal human osteoblasts, subchondral osteoblasts, placental syncytiotrophoblasts, and the gastric epithelium. This hormone regulates bone metabolism and food intake after it binds to its receptors in the hypothalamus (80). Moreover, leptin exhibits additional important metabolic effects on peripheral tissues of liver, skeletal muscle, and bone marrow. In CKD patients, serum levels of leptin are increased with a decline in GFR. Leptin may be implicated in patients with CKD in hematopoiesis, nutrition, and bone metabolism. Increased leptin levels seem to be a risk factor for CKD development (80).

Shankar et al conducted a large cross-sectional study which included 5,000 patients, and revealed that the risk of CKD development significantly increases as blood levels of leptin rise (81). Leptin may be involved in CKD pathogenesis and progression through two mechanism. First, by stimulating the sympathetic nervous system, it promotes renal sodium reabsorption and increases blood pressure. Second, leptin may induce renal injury by stimulating renal endothelial cell proliferation, increased mesangial cell production, which leads to renal scarring by collagen type I and IV production, renal fibrosis, and proteinuria (81-84).

Canpolat et al studied CKD patients divided into four groups (patients with non-dialysis, dialysis, kidney transplant and control group) and evaluated levels of leptin. Plasma levels of leptin did not differ at all in the four mentioned groups (85). Noor and co-researchers conducted a cross-sectional study at the Nephrology Department of Jinnah Post Graduate Medical Center from January 2014 to September 2014, which included CKD patients divided by GFR values in II, III, and IV stages. The study excluded CKD patients with DM, steroid therapy 


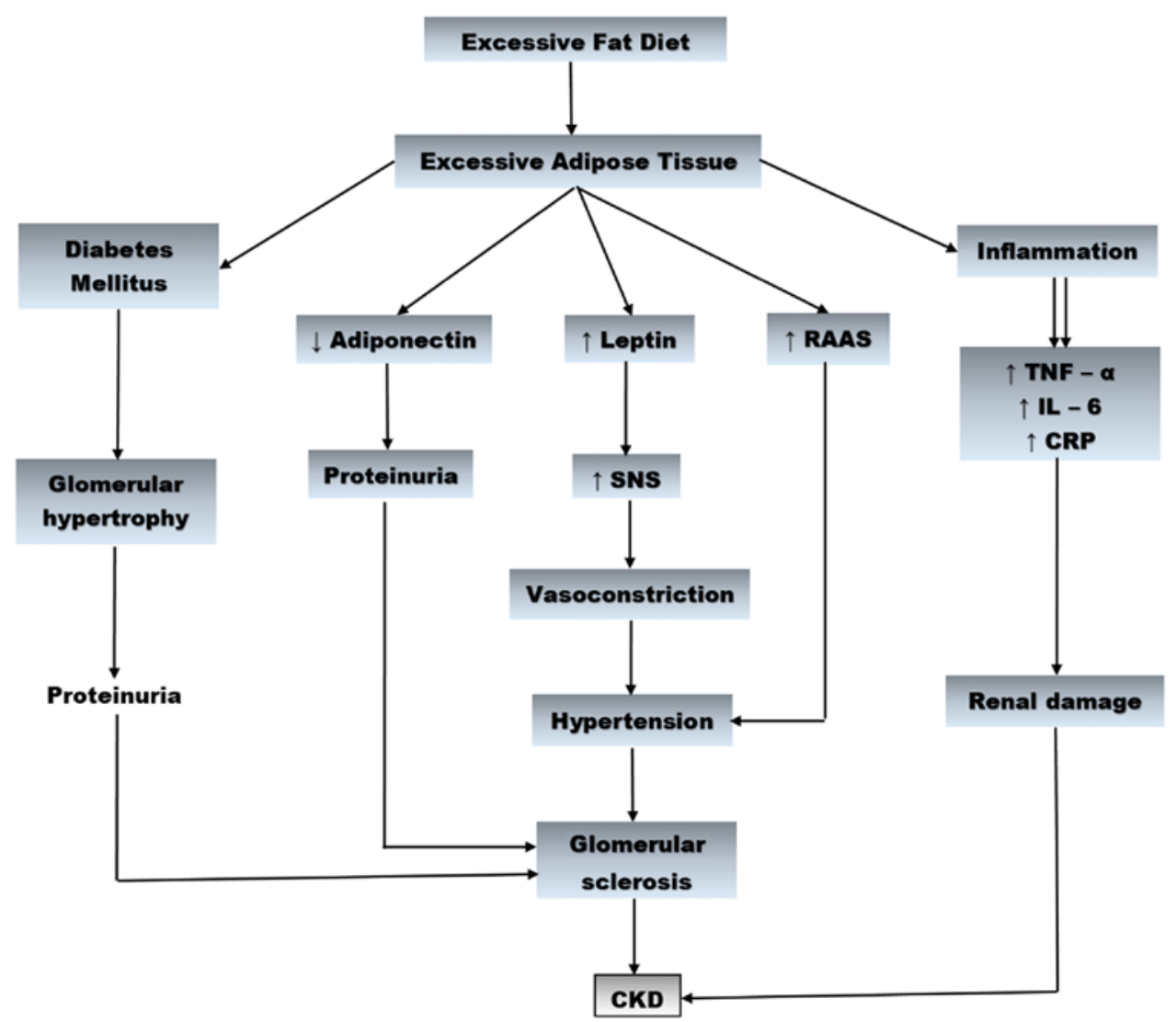

Figure 1. The involvement of obesity in the pathophysiology of CKD [image adapted from Silva and Matos (92)]. CDK, chronic kidney disease; RAAS, renin angiotensin-aldosterone system; TNF, tumor necrosis factor; IL, interleukin; CRP, C-reactive protein; SNS, sympathetic nervous system.

and any inflammatory disease. Serum leptin, CRP, and lipid profile (HDL, LDL) were measured. The serum levels of leptin and CRP were increased with CKD progression. The control group presented increased HDL/LDL ratio vs. the CKD group $(\mathrm{P}<0.001)$. Leptin presented a positive correlation with CRP $(r=0.994 ; P<0.001)$, suggesting that inflammation contributes to hyperleptinemia, and a negative correlation with HDL/LDL ratio ( $\mathrm{r}=-0.403 ; \mathrm{P}<0.001)$ was also observed $(86)$.

Studies performed in-vitro and in animals have demonstrated that leptin and adiponectin may mediate pathological and functional changes in renal parenchyma $(87,88)$. Elevated leptin levels have also been detected in diabetic and obese non-diabetic CKD patients $(89,90)$. Korczyńska et al reported that leptin gene expression from subcutaneous adipose tissue of patients with CKD contributes to elevated serum leptin levels. In patients with CKD, serum levels of leptin were three times higher both in men and women, compared with healthy controls. In CKD women, serum leptin levels were two times higher than in men. The study also revealed that the mRNA level for leptin gene expression from subcutaneous adipose tissue of CKD patients was three times higher compared with that noted in the controls. In addition, total saturated fatty acids (SFA) and monounsaturated FA (MUFA) presented higher serum levels in CKD patients vs. the control group. Serum levels of total $n-3$ polyunsaturated FAs (n-3PUFAs) and $n-6$ polyunsaturated (n-6 PUFAs) were decreased in patients with CKD vs. healthy controls. To test whether the serum FA has an impact on adipose leptin gene expression, 3T3-L1 adipocyte cells were treated with various FAs; such as
SFA (palmitic acid 16:0; PA), MUFA (oleic acid 18:1, OA), n-3 PUFA (docosahexaenoic acid 22:6 n-3 DHA) and n-6 PUFA (arachidonic acid 20:4 n-6 AA) at different concentrations. After $48 \mathrm{~h}$ of incubation with PA and OA, it was observed that FAs, which were increased in serum CKD patients, contributed to elevated leptin gene expression. Instead, DHA and AA FAs, which were decreased in the serum of patients with CKD, had decreased expression of the leptin gene (91). Collectively, inflammation, OS, RAAS activation, changes in leptin and adiponectin levels, increased secretion of insulin and insulin resistance, contribute to CKD development (Fig. 1).

\section{Conclusions}

Diabetic and hypertensive overweight and obese patients present an increased risk to develop CKD. Higher amounts of fat in diet leads to renal fat accumulation, which is associated with hypertension. Obesity affects renal hemodynamic by increasing blood pressure, pulse rate, and RAAS activity, by reducing GFR and by inducing histological perturbations. Decreased adiponectin level, increased leptin level, increased secretions of proinflammatory cytokines and activation of RAAS, result in the development of glomerulopathy. Chronic obesity is involved in glomerular hyperfiltration, glomerular hypertrophy, promotes proteinuria, glomerulomegaly and focal and segmental glomerulosclerosis. Weight loss has beneficial effects on the entire body, including renal functions, which are associated even with the improvement in glomerular hemodynamics. 


\section{Acknowledgements}

Not applicable.

\section{Funding}

No funding was received.

\section{Availability of data and materials}

All information in this review is documented by relevant references.

\section{Authors' contributions}

DM, DGB, AT, OS, IAV, DAM, CCP, ME, ASN, AEN and CS designed the study, performed the literature search and selected the included studies and wrote the manuscript. DM, DGB, AT, OS, IAV, DAM, CCP, ME, ASN, AEN and CS critically revised the manuscript. All authors read and approved the final manuscript. The contributions of all the authors on this review are greatly valued and appreciated.

\section{Ethics approval and consent to participate}

Not applicable.

\section{Patient consent for publication}

Not applicable.

\section{Competing interests}

The authors declare that they have no competing interests.

\section{References}

1. Abed AB, Kavvadas $\mathrm{P}$ and Chadjichristos CE: Functional roles of connexins and pannexins in the kidney. Cell Mol Life Sci 72 2869-2877, 2015.

2. Dantzler WH: Challenges and intriguing problems in comparative renal physiology. J Exp Biol 208: 587-594, 2005.

3. Iglesias P, Bajo MA, Selgas R and Díez JJ: Thyroid dysfunction and kidney disease: An update. Rev Endocr Metab Disord 18: 131-144, 2017.

4. Mandita A, Timofte D, Balcangiu-Stroescu AE, Balan D, Raducu L, Tanasescu MD, Diaconescu A, Dragos D, Cosconel CI, Stoicescu SM and Ionescu D: Treatment of high blood pressure in patients with chronic renal disease. Rev Chim Buchar 70: 993-995, 2019.

5. Young RH and Eble JN: The history of urologic pathology: An overview. Histopathology 74: 184-212, 2019.

6. Dan Spinu A, Gabriel Bratu O, Cristina Diaconu C, Maria Alexandra Stanescu A, Bungau S, Fratila O, Bohiltea R and Liviu Dorel Mischianu D: Botulinum toxin in low urinary tract disorders-over 30 years of practice (Review). Exp Ther Med 20: 117-120, 2020.

7. Siew ED and Davenport A: The growth of acute kidney injury: A rising tide or just closer attention to detail? Kidney Int 87: 46-61, 2015 .

8. Khwaja A: KDIGO clinical practice guidelines for acute kidney injury. Nephron Clin Pract 120: C179-C184, 2012.

9. Sanz AB, Sanchez-Niño MD, Martin-Cleary C, Ortiz A and Ramos AM: Progress in the development of animal models of acute kidney injury and its impact on drug discovery. Expert Opin Drug Discov 8: 879-895, 2013.
10. Timofte D, Dragos D, Balcangiu-Stroescu AE, Tănăsescu MD, Gabriela Bălan D, Răducu L, Tulin A, Stiru O and Ionescu D: Abdominal aortic calcification in predialysis patients: Contribution of traditional and uremia-related risk factors. Exp Ther Med 20: 97-102, 2020.

11. Totan A, Balcangiu-Stroescu AE, Melescanu Imre M, Miricescu D, Balan DG, Stanescu II, Ionescu D, Timofte D, Tanasescu MD and Greabu M: XOR-possible correlations with oxidative stress and inflammation markers in the context of diabetic kidney disease. Rev Chim Buchar 70: 1396-1398, 2019.

12. Balcangiu-Stroescu AE, Tanasescu MD, Diaconescu AC, Raducu L, Balan DG, Mihai A, Tanase M, Stanescu II and Ionescu D: Diabetic nephropathy: A concise assessment of the causes, risk factors and implications in diabetic patients. Rev Chim Buchar 69: 3118-3121 2018.

13. Silva Junior GB, Bentes AC, Daher EF and Matos SM: Obesity and kidney disease. J Bras Nefrol 39: 65-69, 2017 (In English, Portuguese).

14. Balan DG, Tanasescu MD, Diaconescu A, Raducu L, Mihai A, Tanase M, Stanescu II, Ionescu D and Balcangiu-Stroescu AE: Nutritional intervention in patients with diabetic renal disease a brief presentation. Rev Chim Buchar 69: 4078-4082, 2018.

15. Zhang $\mathbf{J}$ and Ningning $W$ : Leptin in chronic kidney disease: A link between hematopoiesis, bone metabolism, and nutrition. Int Urol Nephrol 46: 1169-1174, 2014.

16. Andrassy KM: Comments on 'KDIGO 2012 clinical practice guideline for the evaluation and management of chronic kidney disease'. Kidney Int 84: 622-623, 2013.

17. Levey AS, Eckardt KU, Tsukamoto Y, Levin A, Coresh J, Rossert J, De Zeeuw D, Hostetter TH, Lameire N and Eknoyan G: Definition and classification of chronic kidney disease: A position statement from kidney disease: Improving global outcomes (KDIGO). Kidney Int 67: 2089-2100, 2005.

18. KDIGO CKD Work Group: KDIGO 2012 clinical practice guideline for the evaluation and management of chronic kidney disease. Kidney Int Suppl 3: 1-150, 2013.

19. Balcangiu-Stroescu AE, Tanasescu MD, Diaconescu AC, Raducu L, Constantin AM, Balan DG, Tarmure V and Ionescu D: Cardiovascular comorbidities, inflammation and serum albumin levels in a group of hemodialysis patients. Rev Chim Buchar 69: 926-929, 2018

20. Timofte D, Ionescu D, Medrihan L, Mandita A, Rasina A and Damian L: Vascular calcification and bone disease in hemodialysis patients assessment, association and risk factors. Nephrol Dial Transplant 22: 325-326, 2007

21. Craver L, Marco MP, Martínez I, Rue M, Borràs M, Martín ML, Sarró F, Valdivielso JM and Fernández E: Mineral metabolism parameters throughout chronic kidney disease stages 1-5-achievement of K/DOQI target ranges. Nephrol Dial Transplant 22: 1171-1176, 2007.

22. Kovesdy CP, Furth S and Zoccali C; World Kidney Day Steering Committee: Obesity and kidney disease: Hidden consequences of the epidemic. Indian J Nephrol 27: 85-92, 2017.

23. Timofte D, Mandita A, Balcangiu-Stroescu AE, Balan D, Raducu L, Tanasescu MD, Diaconescu A, Dorin D, Cosconel CI and Ionescu D: Hyperuricemia and cardiovascular diseases-clinical and paraclinical correlations. Rev Chim Buchar 70: 1045-1046, 2019.

24. Popa AR, Vesa CM, Uivarosan D, Jurca CM, Isvoranu G, Socea B, Stanescu AM, Iancu MA, Scarneciu I and Zaha DC Cross sectional study regarding the association between sweetened beverages intake, fast-food products, body mass index, fasting blood glucose and blood pressure in the young adults from north-western Romania. Rev Chim 70: 156-160, 2019.

25. Stanescu AM, Grajdeanu IV, Iancu MA, Stoian AP, Bratu OG, Socea B, Socea LI and Diaconu CC: Correlation of oral vitamin $\mathrm{D}$ administration with the severity of psoriasis and the presence of metabolic syndrome. Rev Chim Buchar 69: 1668-1672, 2018.

26. Dan SA, Bratu OG, Marcu DR, Stanciu AE, Gherghiceanu F, Ionita-Radu F, Bungau S, Stanescu AMA and Mischianu D: Underactive bladder-an underestimated entity. J Mind Med Sci 7: 23-28, 2020.

27. Nittari G, Scuri S, Petrelli F, Pirillo I, di Luca NM and Grappasonni I: Fighting obesity in children from European world health organization member states. Epidemiological data, medicalsocial aspects, and prevention programs. Clin Ter 170: e223-e230, 2019.

28. Chomba H, Martin HD and Kimywe J: Prevalence and predictors of obesity among 7- to 17-year-old schoolchildren in urban arusha, Tanzania. J Nutr Metab 2019: 3106597, 2019. 
29. Smitka $K$ and Marešová $D$ : Adipose tissue as an endocrine organ: An update on pro-inflammatory and anti-inflammatory microenvironment. Prague Med Rep 116: 87-111, 2015.

30. Maalouf NM, Sakhaee K, Parks JH, Coe FL, Adams-Huet B and Pak CY: Association of urinary $\mathrm{pH}$ with body weight in nephrolithiasis. Kidney Int 65: 1422-1425, 2004.

31. Siener R, Glatz S, Nicolay C and Hesse A: The role of overweight and obesity in calcium oxalate stone formation. Obes Res 12 : 106-113, 2004

32. Tessaro CZ, Ramos CI and Heilberg IP: Influence of nutritional status, laboratory parameters and dietary patterns upon urinary acid excretion in calcium stone formers. J Bras Nefrol 40: 35-43, 2018 (In English, Portuguese).

33. Taylor EN, Stampfer MJ and Curhan GC: Diabetes mellitus and the risk of nephrolithiasis. Kidney Int 68: 1230-1235, 2005.

34. Poore W, Boyd CJ, Singh NP, Wood K, Gower B and Dean GA: Obesity and its impact on kidney stone formation. Rev Urol 22 17-23, 2020.

35. Toto RD, Greene T, Hebert LA, Hiremath L, Lea JP, Lewis JB, Pogue V, Sika M and Wang X; AASK Collaborative Research Group: Relationship between body mass index and proteinuria in hypertensive nephrosclerosis: Results from the African American study of kidney disease and hypertension (AASK) cohort. J Kidney Dis 56: 896-906, 2010.

36. Ejerblad E, Fored CM, Lindblad P, Fryzek J, McLaughlin JK and Nyrén O: Obesity and risk for chronic renal failure. J Am Soc Nephrol 17: 1695-1702, 2006

37. Fox CS, Larson MG, Leip EP, Culleton B, Wilson PW and Levy D: Predictors of new-onset kidney disease in a community-based population. JAMA 291: 844-850, 2004.

38. Hall ME, do Carmo JM, da Silva AA, Juncos LA, Wang Z and Hall JE: Obesity, hypertension, and chronic kidney disease. Int J Nephrol Renovasc Dis 7: 75-88, 2014.

39. Sugerman H, Windsor A, Bessos M and Wolfe L: Intra-abdominal pressure, sagittal abdominal diameter and obesity comorbidity. J Intern Med 241: 71-79, 1997.

40. Hall JE, Crook ED, Jones DW, Wofford MR and Dubbert PM: Mechanisms of obesity-associated cardiovascular and renal disease. Am J Med Sci 324: 127-137, 2002.

41. Eckel RH, Barouch WW and Ershow AG: Report of the national heart, lung, and blood institute-national institute of diabetes and digestive and kidney diseases working group on the pathophysiology of obesity-associated cardiovascular disease. Circulation 105: 2923-2928, 2002.

42. Dwyer TM, Bigler SA, Moore NA, Carroll JF and Hall JE: The altered structure of renal papillary outflow tracts in obesity. Ultrastruct Pathol 24: 251-257, 2000.

43. Dwyer TM, Banks SA, Alonso-Galicia M, Cockrell K, Carroll JF, Bigler SA and Hall JE: Distribution of renal medullary hyaluronan in lean and obese rabbits. Kidney Int 58: $721-729,2000$.

44. Chandra A, Neeland IJ, Berry JD, Ayers CR, Rohatgi A, Das SR, Khera A, McGuire DK, de Lemos JA and Turer AT: The relationship of body mass and fat distribution with incident hypertension: Observations from the Dallas heart study. J Am Coll Cardiol 64 997-1002, 2014

45. Pinto-Sietsma SJ, Navis G, Janssen WM, de Zeeuw D, Gans RO and de Jong PE; PREVEND Study Group: A central body fat distribution is related to renal function impairment, even in lean subjects. Am J Kidney Dis 41: 733-741, 2003.

46. Henegar JR, Bigler SA, Henegar LK, Tyagi SC and Hall JE: Functional and structural changes in the kidney in the early stages of obesity. J Am Soc Nephrol 12: 1211-1217, 2001.

47. Rutkowski P, Klassen A, Sebekova K, Bahner U and Heidland A: Renal disease in obesity: The need for greater attention. J Ren Nutr 16: 216-223, 2006.

48. De Jong PE, Verhave JC, Pinto-Sietsma SJ and Hillege HL; PREVEND study group: Obesity and target organ damage: The kidney. Int J Obes Relat Metab Disord 26 (Suppl 4): S21-S24, 2002.

49. Mascali A, Franzese O, Nisticò S, Campia U, Lauro D, Cardillo C, Di Daniele N and Tesauro M: Obesity and kidney disease: Beyond the hyperfiltration. Int J Immunopathol Pharmacol 29: 354-363, 2016

50. Amann K and Benz K: Structural renal changes in obesity and diabetes. Semin Nephrol 33: 23-33, 2013.

51. Kambham N, Markowitz GS, Valeri AM, Lin J and D'Agati VD: Obesity-related glomerulopathy: An emerging epidemic. Kidney Int 59: 1498-1509, 2001
52. Tsuboi N, Utsunomiya Y, Kanzaki G, Koike K, Ikegami M, Kawamura $\mathrm{T}$ and Hosoya T: Low glomerular density with glomerulomegaly in obesity-related glomerulopathy. Clin J Am Soc Nephrol 7: 735-741, 2012

53. Okabayashi Y, Tsuboi N, Sasaki T, Haruhara K, Kanzaki G, Koike K, Miyazaki Y, Kawamura T, Ogura M and Yokoo T: Glomerulopathy associated with moderate obesity. Kidney Int Rep 1: 250-255, 2016.

54. Tsuboi N, Utsunomiya $\mathrm{Y}$ and Hosoya T: Obesity-related glomerulopathy and the nephron complement. Nephrol Dial Transplant 28 (Suppl 4): iv108-iv113, 2013.

55. Wickman $\mathrm{C}$ and Kramer H: Obesity and kidney disease: Potential mechanisms. Semin Nephrol 33: 14-22, 2013.

56. Cassis LA, Police SB, Yiannikouris F and Thatcher SE: Local adipose tissue renin-angiotensin system. Curr Hypertens Rep 10: 93-98, 2008.

57. Marcus Y, Shefer G and Stern N: Adipose tissue renin-angiotensin-aldosterone system (RAAS) and progression of insulin resistance. Mol Cell Endocrinol 378: 1-14, 2013.

58. Cabandugama PK, Gardner MJ and Sowers JR: The renin angiotensin aldosterone system in obesity and hypertension: Roles in the cardiorenal metabolic syndrome. Med Clin North Am 101: 129-137, 2017.

59. Vincent HK and Taylor AG: Biomarkers and potential mechanisms of obesity-induced oxidant stress in humans. Int J Obes (Lond) 30: 400-418, 2006.

60. Boustany CM, Bharadwaj K, Daugherty A, Brown DR, Randall DC and Cassis LA: Activation of the systemic and adipose renin-angiotensin system in rats with diet-induced obesity and hypertension. Am J Physiol Regul Integr Comp Physiol 287: R943-R949, 2004

61. Rüster $\mathrm{C}$ and Wolf G: The role of the renin-angiotensin-aldosterone system in obesity-related renal diseases. Semin Nephrol 33: 44-53, 2013.

62. Papacocea T, Buraga I, Papacocea R, Badarau AI, Buraga M, Ciornei C, Mihai G, Stoian I and Adam D: Antioxidant enzymes-potential targets in intracerebral haemorrhage. Farmacia 62: 1118, 2014.

63. Olariu L, Dumitriu B, Craciun L, Buse E, Rosoiu N, Bojinca M and Papacocea T: The in vitro influence of a pharmaceutically active small sea fish extract on apoptosis and proliferation mechanisms amplified by inflammatory conditions. Farmacia 66: 524-529, 2018.

64. Gómez-Hernández A, Beneit N, Díaz-Castroverde S and Escribano Ó: Differential role of adipose tissues in obesity and related metabolic and vascular complications. Int J Endocrinol 2016: 1216783, 2016.

65. Le Jemtel TH, Samson R, Milligan G, Jaiswal A and Oparil S: Visceral adipose tissue accumulation and residual cardiovascular risk. Curr Hypertens Rep 20: 77, 2018.

66. Shinar S, Berger H, De Souza LR and Ray JG: Difference in visceral adipose tissue in pregnancy and postpartum and related changes in maternal insulin resistance. J Ultrasound Med 38: 667-673, 2019.

67. Reijrink M, de Boer SA, Spoor DS, Lefrandt JD, Lambers Heerspink HJ, Boellaard R, Greuter MJ, Borra RJ, Hillebrands JL, Slart RH and Mulder DJ: Visceral adipose tissue volume is associated with premature atherosclerosis in early type 2 diabetes mellitus independent of traditional risk factors. Atherosclerosis 290: 87-93, 2019.

68. Papacocea IR, Badarau IA, Ciornei MC, Burciulescu SL and Papacocea MT: The effects of caffeine intake on cardiovascular parameters in sleep deprived medical residents. Rev Chim Buchar 70: 1445-1448, 2019.

69. Rhee CM, Ahmadi SF and Kalantar-Zadeh K: The dual roles of obesity in chronic kidney disease: A review of the current literature. Curr Opin Nephrol Hypertens 25: 208-216, 2016.

70. Unger RH, Scherer PE and Holland WL: Dichotomous roles of leptin and adiponectin as enforcers against lipotoxicity during feast and famine. Mol Biol Cell 24: 3011-3015, 2013.

71. Kadowaki T, Yamauchi T, Kubota N, Hara K, Ueki K and Tobe K: Adiponectin and adiponectin receptors in insulin resistance, diabetes, and the metabolic syndrome. J Clin Invest 116: 1784-1792, 2006

72. Slee AD: Exploring metabolic dysfunction in chronic kidney disease. Nutr Metab (Lond) 9: 36, 2012.

73. Run $\mathrm{H}$ and Dong LQ: Adiponectin signaling and function in insulin target tissues. J Mol Cell Bio 8: 101-109, 2016. 
74. Kuo IC, Wu PH, Lin HY, Niu SW, Huang JC, Hung CC, Chiu YW and Chen HC: The association of adiponectin with metabolic syndrome and clinical outcome in patients with non-diabetic chronic kidney disease. PLoS One 14: e0220158, 2019.

75. Coimbra S, Reis F, Nunes S, Viana S, Valente MJ, Rocha S, Catarino C, Rocha-Pereira P, Bronze-da-Rocha E, SameiroFaria M, et al: The protective role of adiponectin for lipoproteins in end-stage renal disease patients: Relationship with diabetes and body mass index. Oxid Med Cell Longev 2019: 3021785, 2019.

76. Yaturu S, Reddy RD, Rains J and Jain SK: Plasma and urine levels of resistin and adiponectin in chronic kidney disease. Cytokine 37: 1-5, 2007.

77. Papacocea T, Papacocea R, Rădoi M, Pițuru S and Balan DG: Stomach 'tastes' the food and adjusts its emptying: A neurophysiological hypothesis (Review). Exp Ther Med 20: 2392-2395, 2020

78. Choi HM, Doss HM and Kim KS: Multifaceted physiological roles of adiponectin in inflammation and diseases. Int $\mathbf{J}$ Mol Sci 21: 1219, 2020

79. Briffa JF, McAinch AJ, Poronnik P and Hryciw DH: Adipokines as a link between obesity and chronic kidney disease. Am J Physiol Renal Physiol 305: F1629-F1636, 2013.

80. Tesauro M, Mascali A, Franzese O, Cipriani S, Cardillo C and Di Daniele N: Chronic kidney disease, obesity, and hypertension: The role of leptin and adiponectin. Int J Hyperten 2012: 943605, 2012.

81. Shankar A, Syamala S, Xiao J and Muntner P: Relationship between plasma leptin level and chronic kidney disease. Int J Nephrol 2012: 269532, 2012.

82. Nasrallah MP and Ziyadeh FN: Overview of the physiology and pathophysiology of leptin with special emphasis on its role in the kidney. Semin Nephrol 33: 54-65, 2013.

83. Han DC, Isono M, Chen S, Casaretto C Hong SW, Wolf G and Ziyadeh FN: Leptin stimulates type I collagen production in $\mathrm{db} / \mathrm{db}$ mesangial cells: Glucose uptakeand TGF-beta type II receptor expression. Kidney Int 59: 1315-1323, 2001.

84. Mao S, Fang L, Liu F, Jiang S, Wu L and Zhang J: Leptin and chronic kidney diseases. J Recept Signal Transduct Res 38 89-94, 2018.
85. Canpolat N, Sever L, Agbas A, Tasdemir M, Oruc C, Ekmekci OB and Caliskan S: Leptin and ghrelin in chronic kidney disease: Their associations with protein-energy wasting. Pediatr Nephrol 33: 2113-2122, 2018.

86. Noor S, Alam F, Fatima SS, Khan M and Rehman R: Role of leptin and dyslipidemia in chronic kidney disease. Pak J Pharm Sci 31: 893-897, 2018.

87. Sharma K, Ramachandrarao S, Qiu G, Usui HK, Zhu Y, Dunn SR, Ouedraogo R, Hough K, McCue P, Chan L, et al: Adiponectin regulates albuminuria and podocyte function in mice. J Clin Invest 118: 1645-1656, 2008.

88. Lee MP, Orlov D and Sweeney G: Leptin induces rat glomerular mesangial cell hypertrophy, but does not regulate hyperplasia or apoptosis. Int J Obes (Lond) 29: 1395-1401, 2005.

89. Galletti F, D'Elia L, Barba G, Siani A, Cappuccio FP, Farinaro E, Iacone R, Russo O, De Palma D, Ippolito R and Strazzullo P: High-circulating leptin levels are associated with greater risk of hypertension in men independently of body mass and insulin resistance: Results of an eight-year follow-up study. J Clin Endocrinol Metab 93: 3922-3926, 2008

90. Lu JW, Chi PJ, Lin YL, Wang CH and Hsu BG: Serum leptin levels are positively associated with aortic stiffness in patients with chronic kidney disease stage 3-5. Adipocyte 9: 206-211, 2010.

91. Korczyńska J, Czumaj A, Chmielewski M, Śledziński M, Mika A and Sledziński T: Increased expression of the leptin gene in adipose tissue of patients with chronic kidney disease-the possible role of an abnormal serum fatty acid profile. Metabolites 10: 98 , 2020.

92. Silva Junior and Matos SMA: Padrões alimentares e doença renal crônica. In Cruz J, Cruz HMM, Kirsztajn GM, Oliveira RB, Barros RT, eds. Atualidades em Nefrologia 14. São Paulo: Sarvier, 2016

This work is licensed under a Creative Commons Attribution-NonCommercial-NoDerivatives 4.0 International (CC BY-NC-ND 4.0) License. 